\title{
Synthesis and Photophysical Properties of Bispsoralen Derivatives Linked by a Bisamide-polymethylene Chain
}

\author{
Dong Jin Yoo \\ Department of Chemistry, Seonam University, Namwon, Chonbuk 590-711, Korea. E-mail: psoralen@korea.com \\ Received July 21, 2007
}

\begin{abstract}
New bispsoralen derivatives 5-10, 8-MOP-NICO(CII $)_{n}$ CONI-8-MOP (BPSB $\Lambda$ - $\mathrm{Cn}, n=0,1,2,3,4$ and 5) in which 5 position of an 8-methoxypsoralen (8-MOP) is linked by various lengths of bisamide polymethylene chain to 5 position of the other 8-MOP, have been synthesized by the amidation of 5-amino-8-methoxypsoralen (12) with $\alpha, \omega$-alkanoyl dichloride. Photophysical properties of their derivatives including $\pi-\pi$ stacking interaction between the two aromatic moieties were investigated by UV absorption and fluorescence emission spectra. Efficient ring-ring stacking interactions have been observed in BPSB $A-C 4$ (9) from the percent hypochromism (\%II) of the models.
\end{abstract}

Key Words : 8-Methoxypsoralen, Bispsoralen derivatives, UV absorption, Fluorescence emission spectra, Ring-ring stacking interaction

\section{Introduction}

Psoralens (Ps) are widely used as dermal photosensitizing agents for the treatment of various skin diseases, such as vitiligo, psoriasis, mycosis fungoides, chronic leukemia, and some infections connected with AIDS and as chemical tools for the study of nucleic acid structure-function relationship. ${ }^{1-5}$ A large number of studies on the mechanism of the photochemical reactions between psoralen and DNA bases in vivo or with thymine derivatives have been carried out. These studies involved intermolecular processes leading generally to a mixture of several photoproducts. Binding of psoralens to $\mathrm{DNA}^{6.7}$ is generally the consequence of two successive events: (a) intercalation of the psoralens between the base pairs of nucleic acids in the ground state; (b) [2+2] type photoaddition of the complexed psoralens to pyrimidine bases of DNA. The 3,4-pyrone and/or 4, 5'-furan double bonds of the psoralen molecules add to pyrimidine 5,6 double bond. ${ }^{8}$ The formation of the intercalated complex between psoralens and DNA is an important step, which markedly affects the successive covalent photobinding to the macromolecule leading to site specificity in addition. The psoralen derivatives are used as a chemical tool to study the relationship between the structure of nucleic acid and the ability to bind psoralen recently based on this site specificity. ${ }^{9-11}$

To investigate these two processes in the absence of complicating factors associated with hydrogen bonding or the usual carbohydrate and phosphodiester linkages, Lhomme

\footnotetext{
Abbreviations: DMF, $N, N$-dimethylformamide; EI, electron impact; FTIR, Fourier transform infrared; HRMS, high resolution mass spectroscopy; HPLC, high-performance liquid chromatography; 8-MOP, 8-methoxypsoralen; PBSBA-C2, 8-MOP-NHCOCH $\mathrm{CH}_{3} ;$ BPSBA$\mathrm{Cn}$, Bispsoralen bisamide polymethylene (8-MOP-NHCO $\left(\mathrm{CH}_{2}\right)_{n} \mathrm{CONH}-$ 8-MOP); NMR, nuclear magnetic resonance; PL, phololuminescence; Ps, psoralen; PUVA, psoralen + UVA; THF, tetrahydrofuran; TMS, tetramethylsilane; UV, ultraviolet; UVA, $320-400 \mathrm{~nm}$ radiation.
}

and Decout ${ }^{12-15}$ prepared a series of model compounds (3) starting from 8-hydroxypsoralen (2) and showed that the polymethylene bridges control the intramolecular ring-ring stacking of the two chromophores in the molecules. Castellan et $a .^{16}$ also investigated the interactions and the photoreactions of synthetic psoralens containing psoralen and thymine rings, two psoralen rings, or two thymine rings. Recently, because of the importance of interaction between the 8-methoxypsoralen and purine base pairs in DNA, Yoo et al. reported preparation of some 8-methoxypsoralenadenine $\left(\mathrm{MOPCH}_{2} \mathrm{OCnAd}\right)$ model compounds, the bifunctional psoralen derivatives containing an adenine as electron donor linked by a varying length of polymethylene bridges starting from $\mathbf{1}$, and studied some photophysical properties including intramolecular ring-ring stacking interactions between the two aromatic moieties. ${ }^{17}$

It seemed to be of great significance in relation to previous works to study new bispsoralen analogs whose structures allow cross-linking of DNA. Hence, in this paper, synthetic models BPSBA-Cn (5-10) in which the psoralens are linked by a bisamide-polymethylene chain to psoralens, thymine, and adenine were devised. Photophysical properties of new models 5-10 including $\pi-\pi$ stacking interaction between the two aromatic moieties were also reported.

\section{Experimental Section}

Materials and instruments. All the reactions were carried out under a dry nitrogen atmosphere, unless otherwise stated. The solvents were reagent grade or highperformance liquid chromatography (HPLC) grade and purified according to the literature procedures. ${ }^{18}$ Most of the chemical reagents were purchased from Aldrich chemical $\mathrm{Co}$. and were used as received without further purification in most cases. 8-MOP (1) was obtained from Sigma chemical $\mathrm{Co}$. and purified by recrystallization from methanol. Merck precoated silica gel plates (Art. 5554) with fluorescent 
<smiles>[R]Oc1c2occc2cc2ccc(=O)oc12</smiles>

$1, R=M e$

$2, \mathrm{R}=\mathrm{H}$

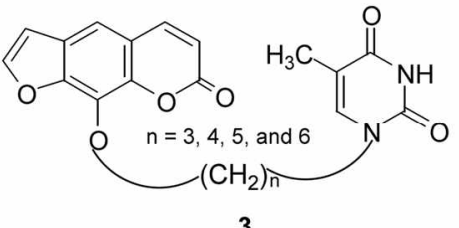

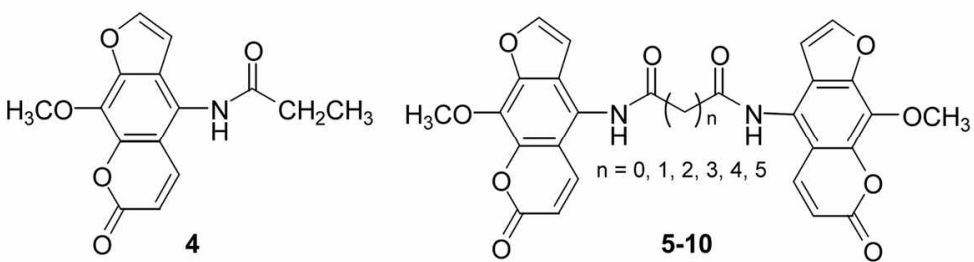

Figure 1. Chemical structures of 8-MOP (1), 8-hydroxypsoralen (2), model compounds 3 of Lhomme and Decout, PSBA-C2 (4), and BPSBA-Cn (5-10).

indicator were used as analytical TLC. Gravity column chromatography and flash chromatography were carried out on a silica gel column (230-400 mesh from Merck).

The ${ }^{1} \mathrm{H}$ nuclear magnetic resonance (NMR) and ${ }^{13} \mathrm{C}$ NMR spectra were recorded on Bruker $\mathrm{AM}-400 \mathrm{MHz}$ and $\mathrm{AM}-$ $300 \mathrm{MHz}$ spectrometers. Proton chemical shifts $(\delta)$ were reported in ppm downfield from tetramethylsilane (TMS), and ${ }^{13} \mathrm{C}$ resonances were recorded using the $39.5 \mathrm{ppm}$ DMSO- $\mathrm{d}_{6}$ resonance peak of the solvent as intemal reference and reported in ppm downfield from TMS. Infrared spectra (IR) spectra were recorded on a Bomem MB-I00 Series FT-IR spectrophotometer. Mass spectra were determined at $70 \mathrm{eV}$ with V.G. AutoSpec Ultma by the electron impact (EI) method. Elemental analysis (EA) data were recorded on EA 1110-Fisons elemental analyzers. Melting points were determined in capillary tubes on a Thomas Hoover capillary melting point apparatus. UV-visible spectra were recorded on a Shimadzu UV-3100S spectrophotometer. Fluorescence spectra were recorded on a Perkin-Elmer LS50 luminescence spectrometer with a gated photomultiplier tube detector at room temperature (excitation source at 350 $\mathrm{nm}$ ).

Synthesis. Individual new bispsoralen and reference compounds were synthesized as follows: 8-MOP-NO $(11$, 5-nitro-8-methoxypsoralen) was obtained from 8-MOP (1) in $89 \%$ yield by the known procedure. ${ }^{19}$ Reduction of 8 -
$\mathrm{MOP}-\mathrm{NO}_{2}(11)$ with $\mathrm{Sn}(\mathrm{II}) \mathrm{Cl}_{2}$ and aqueous $\mathrm{HCl}$ solution afforded 8-MOP-NH, (12,5-amino-8-methoxypsoralen) in $94 \%$ yield. The reference molecule (4) was prepared in $73 \%$ yield by the amidation of 12 with propionyl chloride in icebath. $^{20}$ The model compounds (BPSBA-Cn, 5-10) were directly prepared by the amidation of 12 in DMF with $\alpha, \omega$ alkanoyl dichloride in THF at $0^{\circ} \mathrm{C}$ (Scheme 1).

Preparation of PSBA-C2 (4). To a stirred solution of 8 MOP-NH $2(12,0.20 \mathrm{~g}, 0.87 \mathrm{mmol})$ in DMF $(3 \mathrm{~mL})$ under argon gas was added propionyl chloride $(80.0 \mathrm{mg}, 0.87$ $\mathrm{mmol})$ in THF $(50 \mathrm{~mL})$ dropwise at $0^{\circ} \mathrm{C}$ for $2 \mathrm{~h}$. The reaction mixture was filtered, washed with methanol and dried in vacho to give compound $4(0.18 \mathrm{~g}, 73 \%)$ : $\mathrm{mp} 223-$ $224{ }^{\circ} \mathrm{C} ;{ }^{1} \mathrm{H}$ NMR (400 MHz, DMSO-d $) \delta 1.15(\mathrm{t}, 3 \mathrm{H}, J=$ $7.6 \mathrm{~Hz}), 2.50(\mathrm{t}, 2 \mathrm{H}, J=7.6 \mathrm{~Hz}), 4.15(\mathrm{~s}, 3 \mathrm{H}), 6.42(\mathrm{~d}, 1 \mathrm{H}, J$ $=9.8 \mathrm{~Hz}), 6.87(\mathrm{~d}, 1 \mathrm{H}, J=2.2 \mathrm{~Hz}), 7.98(\mathrm{~d}, 1 \mathrm{H}, J=9.8 \mathrm{~Hz})$, 8.07 (d, IH, $J=2.2 \mathrm{~Hz}), 10.08(\mathrm{~s}, 1 \mathrm{H}) ;{ }^{13} \mathrm{C} \mathrm{NMR}(100 \mathrm{MHz}$, DMSO-d 6 ) $\delta 9.72,28.63,61.11,106.35,111.92,113.38$, $121.72,122.82,130.19,141.92,142.65,146.90,147.03$, $159.44,172.80 ;$ IR $\left(\mathrm{cm}^{-1}\right) 3431,3246,3133,3102,2980$, $2949,2903,1723,1656,1592,1517,1481,1381,1227$, $1165,1138,1082,1049,1035,940,852,755$; Mass (m/e, \%) 287 (42), 230 (54), 216 (100), 159 (11), 57 (58); HRMS calcd for $\mathrm{C}_{15} \mathrm{H}_{13} \mathrm{NO}_{5}: 287.0794$, found: 287.0799 .

Preparation of BPSBA-C0 (5). Reaction of 8-MOP-NH, $(12,0.30 \mathrm{~g}, 1.30 \mathrm{mmol})$ in DMF (2 mL) with oxalyl chloride<smiles>COc1c2cc(S(=O)(=O)O)ccc2cc2ccoc12</smiles>

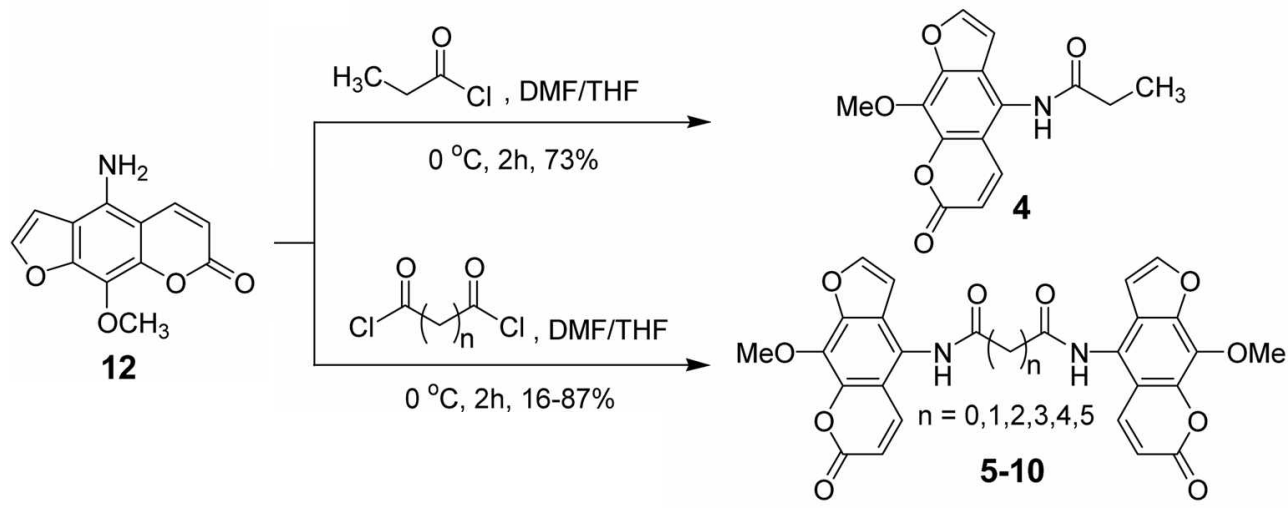

Scheme 1. Synthesis of the reference, PSBA-C2 (4) and the model compounds, BPSBA-Cn (5-10). 
$(82.0 \mathrm{mg}, 0.65 \mathrm{mmol})$ in THF $(70 \mathrm{~mL})$ was carried out as described for the preparation of 4 to obtain compound 5 $(0.29 \mathrm{~g}, 87 \%)$ : mp $326-327{ }^{\circ} \mathrm{C} ;{ }^{1} \mathrm{H}$ NMR $(300 \mathrm{MHz}$, DMSO-d 6$) \delta 4.19(\mathrm{~s}, 6 \mathrm{H}), 6.45(\mathrm{~d}, 2 \mathrm{H}, J=9.8 \mathrm{~Hz}), 7.10(\mathrm{~d}$, $2 \mathrm{H}, J=2.2 \mathrm{~Hz}), 8.11(\mathrm{~d}, 2 \mathrm{H}, J=2.2 \mathrm{~Hz}), 8.19(\mathrm{~d}, 2 \mathrm{H}, J=9.8$ $\mathrm{Hz}), 11.19(\mathrm{~s}, 2 \mathrm{H})$; ${ }^{13} \mathrm{C} \mathrm{NMR}\left(75 \mathrm{MHz}, \mathrm{DMSO}-\mathrm{d}_{6}\right) \delta 61.33$, $106.87,112.75,113.71,120.36,123.66,131.08,142.01$, $142.71,146.97,147.36,159.42,159.68 ;$ IR $\left(\mathrm{cm}^{-1}\right) 3437$, $3367,3270,3123,3037,2955,2892,1735,1686,1591$, $1500,1423,1383,1315,1207,1158,1045,949,827,752$; Mass (m/e, \%) $516(26), 313(12), 257(18), 231(70), 216$ $(60), 117(49), 111(37), 97(57), 84(65), 71(73), 66(65)$, 57 (100); Anal. Calcd. for $\mathrm{C}_{26} \mathrm{H}_{16} \mathrm{~N}_{2} \mathrm{O}_{10}: \mathrm{C}(60.47 \%), \mathrm{H}$ $(3.12 \%), \mathrm{N}(5.43 \%)$. Found: C $(60.02 \%), \mathrm{H}(3.09 \%), \mathrm{N}$ $(5.45 \%)$.

Preparation of BPSBA-C1 (6). Reaction of 8-MOP-NH $(12,0.20 \mathrm{~g}, 0.87 \mathrm{mmol})$ in DMF (2 $\mathrm{mL})$ with malonyl dichloride $(61.0 \mathrm{mg}, 0.43 \mathrm{mmol})$ in THF $(70 \mathrm{~mL})$ was carried out as described for the preparation of 4 to obtain compound 6 (36.5 mg, 16\%): mp 271-273 ${ }^{\circ} \mathrm{C}$; 'H NMR (300 $\left.\mathrm{MHz}, \mathrm{DMSO}-\mathrm{d}_{6}\right) \delta 3.78(\mathrm{~s}, 2 \mathrm{H}), 4.18(\mathrm{~s}, 6 \mathrm{H}), 6.45(\mathrm{~d}, 2 \mathrm{H}, J$ $=9.8 \mathrm{~Hz}), 6.96(\mathrm{~d}, 2 \mathrm{H}, J=2.2 \mathrm{~Hz}), 8.09(\mathrm{~d}, 2 \mathrm{H}, J=2.2 \mathrm{~Hz})$, $8.13(\mathrm{~d}, 2 \mathrm{H}, J=9.8 \mathrm{~Hz}), 10.46(\mathrm{~s}, 2 \mathrm{H}),{ }^{13} \mathrm{C} \mathrm{NMR}(75 \mathrm{MHz}$, DMSO-d $\left.\mathrm{d}_{6}\right) \delta 30.65,61.14,106.26,112.25,113.77,121.04$, $123.16,130.55,141.19,142.64,146.97,147.16,159.42$, 166.77; IR $\left(\mathrm{cm}^{-1}\right) 3441,3243,3120,3103,3001,2953$, $2862,1733,1641,1587,1510,1473,1412,1389,1201$, $1165,1132,1051,1039,963,948,829,751$; Mass $(\mathrm{m} / \mathrm{e}, \%)$ $530(2), 446(2), 257(52), 232$ (61), 231 (98), $217(67), 216$ (100), $188(68), 170(46), 160(35), 132(36), 120(56), 104$ (30), $80(54), 77$ (27), 52 (32); HRMS calcd for $\mathrm{C}_{27} \mathrm{H}_{18} \mathrm{~N}_{2} \mathrm{O}_{10}$ : 530.0962 , found: 530.0978 .

Preparation of BPSBA-C2 (7). Reaction of 8-MOP-NH $(12,0.20 \mathrm{~g}, 0.87 \mathrm{mmol})$ in DMF (3 mL) with succinyl chloride $(67.0 \mathrm{mg}, 0.43 \mathrm{mmol})$ in THF $(70 \mathrm{~mL})$ was carried out as described for the preparation of $\mathbf{4}$ to obtain compound $7(0.12 \mathrm{~g}, 50 \%)$ : mp 332-334 ${ }^{\circ} \mathrm{C}$; ${ }^{1} \mathrm{H}$ NMR $(300 \mathrm{MHz}$, DMSO- $\left.\mathrm{d}_{6}\right) \delta 2.86(\mathrm{~s}, 4 \mathrm{H}), 4.15(\mathrm{~s}, 6 \mathrm{H}), 6.34(\mathrm{~d}, 2 \mathrm{H}, J=9.8$ $\mathrm{Hz}), 6.86(\mathrm{~d}, 2 \mathrm{H}, J=2.2 \mathrm{~Hz}), 8.02(\mathrm{~d}, 2 \mathrm{H}, J=2.2 \mathrm{~Hz}), 8.05$ (d, $2 \mathrm{H}, J=9.8 \mathrm{~Hz}), 10.23(\mathrm{~s}, 2 \mathrm{H}) ;{ }^{13} \mathrm{C}$ NMR $(75 \mathrm{MHz}$, DMSO-d 6 ) $\delta 30.80,30.90,61.26,106.86,112.00,113.15$, $122.13,123.03,130.19,141.97,142.74,146.83,147.13$, $159.62,171.73$; IR $\left(\mathrm{cm}^{-1}\right) 3437,3251,3167,3142,3037$, $2947,2868,1724,1647,1592,1520,1481,1424,1380$, $1320,1141,1050,975,950,829,754$; Anal. Calcd. for $\mathrm{C}_{28} \mathrm{H}_{20} \mathrm{~N}_{2} \mathrm{O}_{10}: \mathrm{C}(61.76 \%), \mathrm{H}(3.70 \%), \mathrm{N}(5.15 \%)$. Found: $\mathrm{C}$ $(61.71 \%), \mathrm{H}(3.80 \%), \mathrm{N}(5.11 \%)$.

Preparation of BPSBA-C3 (8). Reaction of 8-MOP-NH 2 $(12,0.27 \mathrm{~g}, 1.18 \mathrm{mmol})$ in DMF (3 $\mathrm{mL})$ with glutaryl dichloride $(99.7 \mathrm{mg}, 0.59 \mathrm{mmol})$ in THF $(80 \mathrm{~mL})$ was carried out as described for the preparation of 4 to obtain compound $8(0.25 \mathrm{~g}, 76 \%)$ : mp $338-339{ }^{\circ} \mathrm{C} ;{ }^{1} \mathrm{H}$ NMR ( 300 $\left.\mathrm{MHz}, \mathrm{DMSO}-\mathrm{d}_{6}\right) \delta 1.98-2.07(\mathrm{~m}, 2 \mathrm{H}), 2.64(\mathrm{t}, 4 \mathrm{H}, J=6.8$ $\mathrm{Hz}$ ), 4.10 (s, 6H), 6.33 (d, $2 \mathrm{H}, J=9.8 \mathrm{~Hz}$ ), 6.93 (d, $2 \mathrm{H}, J=$ $1.8 \mathrm{~Hz}), 8.03$ (d, $2 \mathrm{H}, J=1.8 \mathrm{~Hz}), 8.08$ (d, $2 \mathrm{H}, J=9.8 \mathrm{~Hz}$ ), $10.84(\mathrm{~s}, 2 \mathrm{H}) ;{ }^{13} \mathrm{C}$ NMR $(75 \mathrm{MHz}$, DMSO-d 6 ) $\delta 20.98$, $34.79,61.10,106.43,111.90,113.31,121.59,122.83$,
$130.23,141.40,142.63,146.86,147.01,159.39,171.59$; IR $\left(\mathrm{cm}^{-1}\right) 3440,3248,3150,3121,3009,2951,2865,1735$, $1662,1592,1518,1481,1383,1210,1164,1137,1062$, $1030,952,845,824,749$; Anal. Calcd. for $\mathrm{C}_{29} \mathrm{H}_{22} \mathrm{~N}_{2} \mathrm{O}_{10}: \mathrm{C}$ $(62.37 \%), \mathrm{H}(3.97 \%), \mathrm{N}(5.02 \%)$. Found: C $(62.84 \%), \mathrm{H}$ $(4.04 \%), \mathrm{N}(5.10 \%)$.

Preparation of BPSBA-C4 (9). Reaction of 8-MOP-NH $(12,0.15 \mathrm{~g}, 0.65 \mathrm{mmol})$ in DMF $(2 \mathrm{~mL})$ with adipoyl chloride $(59.4 \mathrm{mg}, 0.32 \mathrm{mmol})$ in THF $(50 \mathrm{~mL})$ was carried out as described for the preparation of $\mathbf{4}$ to obtain compound $9(81.0 \mathrm{mg}, 44 \%): \mathrm{mp} 329-330{ }^{\circ} \mathrm{C} ;{ }^{1} \mathrm{H}$ NMR $(300 \mathrm{MHz}$, DMSO-d 6$) \delta 1.78(\mathrm{~s}, 4 \mathrm{H}), 2.58(\mathrm{~s}, 4 \mathrm{H}), 4.13(\mathrm{~s}, 6 \mathrm{H}), 6.36(\mathrm{~d}$, $2 \mathrm{H}, J=9.9 \mathrm{~Hz}), 6.88(\mathrm{~d}, 2 \mathrm{H}, J=2.2 \mathrm{~Hz}), 8.02$ (d, $2 \mathrm{H}, J=9.9$ $\mathrm{Hz}), 8.05$ (d, 2H, $J=2.2 \mathrm{~Hz}), 10.43(\mathrm{~s}, 2 \mathrm{H}) ;{ }^{13} \mathrm{C}$ NMR $(75$ $\mathrm{MHz}_{2}$ DMSO-d $\left.\mathrm{d}_{6}\right) \delta 24.88,35.17,61.13,106.52,111.83$, $113.28,121.78,122.77,130.17,141.52,142.67,146.85$, $147.04,159.45,171.98$; IR $\left(\mathrm{cm}^{-1}\right) 3440,3245,3133,3104$, $3007,2947,2867,1729,1649,1591,1517,1479,1423$, $1380,1208,1163,1138,1054,1031,972,951,828,753$; Mass (m/e, \%) $572(9), 356(56), 342(15), 328(39), 314$ (11), $286(24), 272(22), 257(12), 244(20), 232(40), 231$ (91), $230(31), 217(26), 216(100), 201(10), 188(17), 170$ (12), 120 (8). HRMS calcd for $\mathrm{C}_{30} \mathrm{H}_{24} \mathrm{~N}_{2} \mathrm{O}_{10}: 572.1431$, found: 572.1480 .

Preparation of BPSBA-C5 (10). Reaction of 8-MOP$\mathrm{NH}_{2}(12,0.27 \mathrm{~g}, 1.17 \mathrm{mmol})$ in DMF (3 mL) with pimeloyl chloride $(0.12 \mathrm{~g}, 0.58 \mathrm{mmol})$ in THF $(80 \mathrm{~mL})$ was carried out as described for the preparation of $\mathbf{4}$ to obtain compound $10(0.18 \mathrm{~g}, 52 \%): \mathrm{mp} 283-285^{\circ} \mathrm{C} ;{ }^{1} \mathrm{H}$ NMR $(300 \mathrm{MHz}$, DMSO-d 6 ) $\delta 1.44-1.53(\mathrm{~m}, 2 \mathrm{H}), 1.68-1.82(\mathrm{~m}, 4 \mathrm{H}), 2.48(\mathrm{t}$, $4 \mathrm{H}, J=1.4 \mathrm{~Hz}), 4.13(\mathrm{~s}, 6 \mathrm{H}), 6.29$ (d, $2 \mathrm{H}, J=7.4 \mathrm{~Hz}), 6.81$ $(\mathrm{d}, 2 \mathrm{H}, J=1.5 \mathrm{~Hz}), 7.91$ (d, $2 \mathrm{H}, J=7.4 \mathrm{~Hz}), 7.99$ (d, $2 \mathrm{H}, J=$ $1.5 \mathrm{~Hz}), 10.13(\mathrm{~s}, 2 \mathrm{H}) ;{ }^{13} \mathrm{C}$ NMR (75 MHz, DMSO-d 6 ) $\delta$ $24.96,28.36,35.39,61.12,106.37,111.89,113.35,121.62$, $122.83,130.24,141.28,142.64,146.86,147.03,159.40$, 172.10 ; IR $\left(\mathrm{cm}^{-1}\right) 3439,3252,3143,3119,3008,2946$, $2860,1731,1659,1592,1519,1480,1423,1382,1318$, $1208,1163,1140,1052,974,951,823,751$; Mass $(\mathrm{m} / \mathrm{e}, \%)$ $586(42), 342(26), 339(32), 328(36), 327(52), 254(69)$, $253(100), 236(52), 235(99), 231(59), 230(90), 224(40)$, $216(94), 160(40), 130(45), 120(64), 105(39), 77(39)$; HRMS calcd for $\mathrm{C}_{31} \mathrm{H}_{26} \mathrm{~N}_{2} \mathrm{O}_{10}: 586.1587$, found: 586.1578 .

Determination of the percent of hypochromism $(\% \mathrm{H})$. All UV spectra were measured under the same condition: $2.5 \times 10^{-5} \mathrm{M}, 20{ }^{\circ} \mathrm{C}, 100 \%$ DMF. The percent of hypochromism $(\% \mathrm{H})$ corresponds to an integrated hypochromic effect. The hypochromic effect is defined by the percent of hypochromism $(\% \mathrm{H})=[1-f(\mathrm{BPSBA}-\mathrm{Cn}) / 2 f(\mathrm{PSBA}-\mathrm{C} 2)] \times$ 100 , where $f$ is the oscillator strength of the transition, i.e. a measure of the intensity of absorption $f=4.32 \times 10^{-9} \varepsilon(\lambda) /$ $\lambda^{2} \mathrm{~d} \lambda$, where $\varepsilon(\lambda)$ is the molar absorption coefficient. The $f$ values were obtained from optical densities measured at every $2.5 \mathrm{~nm}$ by application of the Simpson's rule, as described in precedent publications. ${ }^{2122}$ The percent hypochromism $(\% \mathrm{H})$ reflects the stacking of the two chromophores in the molecules and its value is generally considered as a measure of the interactions. 


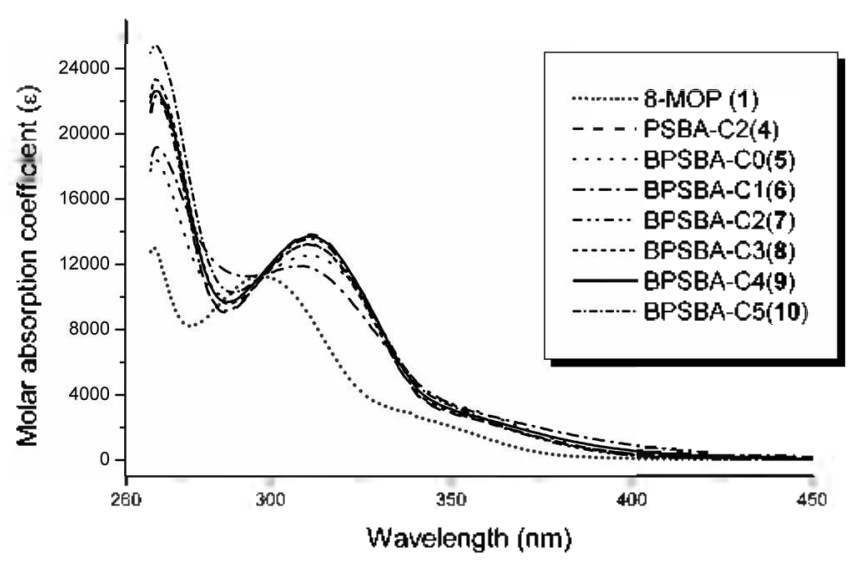

Figure 2. Ultraviolet absorption spectra of BPSBA-Cn (5-10), PSBA-C2 (4), 8-MOP (1). All the spectra were measured under the same conditions: $2.5 \times 10^{-5} \mathrm{M}, 20^{\circ} \mathrm{C}$ in DMF.

\section{Results and Discussion}

UV absorption spectra. UV absorption spectra of the model BPSBA-Cn (5-10) and two reference compounds 8MOP (1) and PSBA-C2 (4) are shown in Figure 2 and Table 2. All the spectra were obtained under the same condition in DMF at $20^{\circ} \mathrm{C}$. The concentrations of the solutions were kept low enough $(\mathrm{ca} .25 \mu \mathrm{M})$ to avoid any intermolecular contribution. ${ }^{13}$ The most striking feature characterizing the relationships between BPSBA-Cn (5-10) and 8-MOP (1) is that absorption maximum of BPSBA-Cn (5-10) (ca. 269 and $313 \mathrm{~nm}$ ) having two aromatic moieties tends to move toward longer wavelengths than 8-MOP (1) (265 and $299 \mathrm{~nm}$ ). BPSBA-Cn shows red-shifted but similar UV absorption pattern as $8-\mathrm{MOP}$ in the range of $310-380 \mathrm{~nm}$, at which psoralen + UVA(PUVA) therapy is conducted.

Percent hypochromism $(\% \mathbf{H})$. The $\% \mathrm{H}$ values calculated in six different regions of the spectra for the six models 5-10 are summarized in Table I. The table indicates that all the systems prepared show appreciable hypochromism which is indicative of substantial intramolecular ring-ring stacking. An interesting point, which needs further investigation, is raised by the comparison of $\% \mathrm{H}$ for the six models 5-10 possessing chains of different lengths. All values are important and remain in the same order. The results clearly indicate that the model compounds 5-10 are in equilibrium of folded or stacked and unfolded conformations. The variation of $\% \mathrm{H}$ values showed a significant difference between three and four atoms in bridging methylene chain, but a slight difference in the linker with more than four atoms as shown in Table 1 . These variations probably reflect a decrease of the proportion of folded or stacked conformations as the length of the linker is decreased or/and the geometrical overlap of the chromophores in the folded or stacked conformations. For BPSBA-C3 (8) and BPSBA-C4 (9), the magnitudes of $\% \mathrm{H}$ determined for the whole spectrum are quite different, suggesting incomparable degrees of stacking for the two compounds. The large differences observed in the values calculated for the different
Table 1. Percent hypochromisin values $(\% \mathrm{H})$ determined for model 5-10 between different wavelength ranges. Spectra measured at $20{ }^{\circ} \mathrm{C}$ in DMF. Relative precision of $\% \mathrm{H}$ is $\pm 0.5 \%$

\begin{tabular}{lrccccc}
\hline $\begin{array}{l}\text { Wave- Model } \\
\text { length }\end{array}$ & $\begin{array}{c}5 \\
(\mathrm{n}=0)\end{array}$ & $\begin{array}{c}6 \\
(\mathrm{n}=1)\end{array}$ & $\begin{array}{c}\mathbf{7} \\
(\mathrm{n}=2)\end{array}$ & $\begin{array}{c}\mathbf{8} \\
(\mathrm{n}=3)\end{array}$ & $\begin{array}{c}\mathbf{9} \\
(\mathrm{n}=4)\end{array}$ & $\begin{array}{c}\mathbf{1 0} \\
(\mathrm{n}=5)\end{array}$ \\
\hline $\begin{array}{c}\text { Range }(\mathrm{nm}) \\
450-310\end{array}$ & -6.3 & 8.1 & 12.3 & 13.9 & 18.3 & 15.9 \\
$450-300$ & -4.0 & 8.2 & 12.3 & 13.8 & 19.2 & 16.3 \\
$450-290$ & -4.3 & 8.5 & 12.4 & 14.0 & 19.7 & 16.6 \\
$450-270$ & 0.0 & 9.3 & 13.3 & 14.2 & 20.6 & 16.4 \\
$340-290$ & -0.9 & 8.9 & 12.3 & 13.6 & 21.3 & 16.9 \\
$340-270$ & -2.9 & 8.2 & 13.4 & 14.0 & 21.8 & 16.7 \\
\hline
\end{tabular}

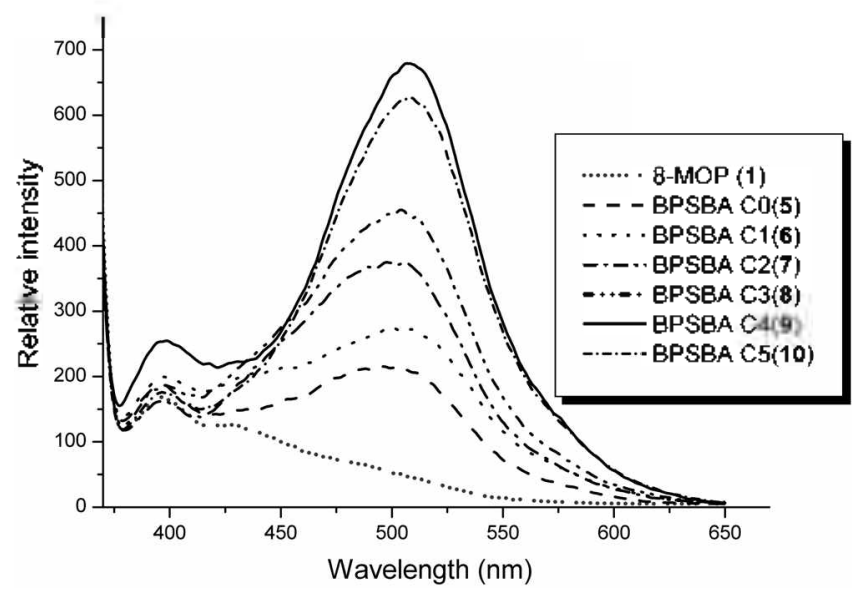

Figure 3. Fluorescence spectra of $\mathrm{BPSB} A-\mathrm{Cn}$ in DMF at roon temperature (cxcitation at $350 \mathrm{nun}$ ).

spectrum portions probably reflect variations in the geometrical overlap of the chromophores in the folded or stacked conformations. This suggests that the complexes adopt different preferred geometries according to the chain length. The model 9 showed the highest value of $\% \mathrm{H}$, which allowed the most efficient ring-ring stacking between two aromatic units linked by bisamide-four methylene chain.

We compared the percent hypochromism value $(\% \mathrm{H})$ of the model compound BPSBA-C4 (9) with that of previously reported 8-methoxypsoralen-adenine $\left(\mathrm{MOPCH}_{2} \mathrm{OCnAd}\right)$ model compounds ${ }^{17 a}$ to study the correlation of $\% \mathrm{H}$ with molecular structures. The maximum $\% \mathrm{H}$ values of $\mathrm{MOPCH}_{2} \mathrm{OC}_{2} \mathrm{Ad}$ were 10.4-18.2, while those of BPSBAC4 (9) were 18.3-21.8 as shown in Table 1. The results indicate that the model compounds, bis-8-methoxypsoralen systems show more efficient $\pi-\pi$ stacking interaction than the 8-methoxypsoralen-adenine pair.

Fluorescence emission spectra. A particular folded or stacked conformation was intended to portray not necessarily a preferred overlap but rather any stacked conformation. ${ }^{23} \mathrm{BPSBA}-\mathrm{Cn}$ could have a number of conformations including unstacked or unfolded and stacked or folded forns. The fluorescence emission spectra of 8-MOP (1) and BPSBA-Cn (5-10) in DMF at room temperature were measured at the same excitation wavelength $(350 \mathrm{~nm})$ shown in 
Table 2. The elcctronic absorption and fluorescence maximum ( $\lambda_{\max }$ ) of 8-MOP (1) and BPSBA-Cn (5-10)

\begin{tabular}{cccccc}
\hline Entry & Compounds & \multicolumn{2}{c}{ UV (nm) } & \multicolumn{2}{c}{ PL (nm) } \\
\hline 1 & 8-MOP (1) & 265 & 299 & 396 & - \\
2 & BPSBA-C0 (5) & 267 & 310 & 397 & 503 \\
3 & BPSBA-C1 (6) & 267 & 307 & 397 & 500 \\
4 & BPSBA-C2 (7) & 267 & 309 & 398 & 500 \\
5 & BPSBA-C3 (8) & 268 & 311 & 398 & 504 \\
6 & BPSBA-C4 (9) & 269 & 313 & 399 & 509 \\
8 & BPSBA-C5 (10) & 268 & 312 & 398 & 507 \\
\hline
\end{tabular}

Figure 3 and Table 2. Although the spectral shapes for all samples were similar having two maximum intensities around 399 and $509 \mathrm{~nm}$, the intensity of all model compounds 5-10 was much stronger than that of 8-MOP (1). Two aromatic units linked by flexible polymethylene bridge could adopt folded and unfolded conformations in solution and the position of the folded $\rightleftharpoons$ unfolded conformational equilibrium was a measure of the intramolecular ring-ring stacking interaction as reported earlier. ${ }^{17 a}$ Interestingly, the model $9(n=4)$ showed much stronger fluorescence than the other compounds $(\mathbf{5}, \mathbf{6}, \mathbf{8}, 10$ and 8-MOP) in agreement with the percent hypochromism $(\% \mathrm{H})$ values. The results indicate that two aromatic units in the compound 9 were well stacked due to strong $\pi-\pi$ stacking interactions resulting in the rigid conformation and consequently, the nonradiative decay paths like internal conversion or intersystem crossing were slowed down leading to strong fluorescence compared to those in the short linker models $(n<3$ ). On the other hand, the compounds $(5,6,7$ and 8 ) having the short linker were probably less stacked due to the diminishing folded conformation resulted from reducing flexibility by two amide bonds.

In conclusion, we have prepared new bifunctional bispsoralen derivatives (BPSBA-Cn, 5-10) allowing the $\pi-\pi$ stacking interactions between two 8-methoxypsoralens. UV absorption and fluorescence emission spectra were obtained and the percent hypochromism studies indicated the most efficient ring-ring stacking interactions in BPSBA-C4 (9). Additionally the model bis-8-methoxypsoralen systems showed more efficient ring-ring stacking interaction than the 8-methoxypsoralen-adenine pair.

\section{References}

I. Scott. B. R.; Pathak, M. A.; Mohn. G. R. Mutat. Res. 1976. 39.29.

2. (a) Parrish, J. A.; Stern, P. S.; Pathak, M. A.; Filzpatrick, T. B. The Science of Photomedicine; Plenum Press: New York, 1982; pp 595-624. (b) Parrish, J. A.; Fitzpatrick, T. B.; Tanenbaum, L.; Pathak. M. A. New Enol. J. Med. 1974. 291, 1207.

3. Edelson, R.; Berget, C.; Gasparro, F.; Jegasothy, B.; Heald, P.; Wintroub, B.; Vonderheid, E.; Knobler, R.; Wolff, K.; Plewig, G.; Mckiernan, G.; Christansen, I.; Oster, M.; Honigsmann, H.; Wilford, H.; Kokoschka, E.; Rehle, T; Perez, M.; Stingl, G.; Laroche, L. New Engl. J. Med. 1987, 3/6, 297.

4. Knobler, R. M.; Honigsmann, H.; Edelson, R. L. Psoralen Phototherapies in Psoralen DNA Photobiolog;, Gasparro, F. T. Ed.; CRC Press: Boca Raton, Florida, 1988; Vol. II, pp 117-134.

5. Gorin, J.; Lessana-Leibowitch, M.; Fortier, P.; Leibowitch, J.; Escande, J.-P. J. Am. Acad. Dermatol. 1989, 20, 51 l.

6. Musajo, L.; Rodighiero, G.; Dall'Acqua, F.; Marciani, S.; Bordon, F.; Bacciccatti, F.; Bevilacqua, R. In Stmlight and Man. 1974, 369.

7. Musajo, L.; Rodighiero, G. Photochem. Photobiol. 1972, 7, 115.

8. Harter, M. L.; Felkner, I. C.; Mantulin, W. W.; Mclnturff, D.; Marx, J. N.; Song, P. S. Photochem. Photobiol. 1974, 20, 407.

9. (a) Cimino, G. P.; Gamper, H. B.; Isaacs, S. T.; Hearst, J. E. Am. Rev, Biochem. 1985, 54, 1151, (b) Hearst, J. E. Am. Rev: Biophys. Bioeng. 1985, 10,69 .

10. Shen, C.-K. J.; Hsieh, T.-S.; Wang. J. C.; Hearst, J. E. J. Mol. Biol. 1977, 116, 66l. (b) Shen, C.-K. J.; Hearst, J. E. Proc. Natl. Acad. Sci. USA 1976, 73, 2649.

11. (a) Yoo, D. J.; Jeon, Y. H.; Kim, D. W.; Han, G. S.; Shim, S. C. Bull. Kor. Chem. Soc. 1996, J7(6), 550. (b) Han, G. S.; Yoo, D. J.; Kim, S. K.; Shim, S. C.; Kang, H. K. Photochem. Phogobiol. 1996, 64(3), 525 .

12. Decout, J. L.; Lhomme, J. Tetrahedron Lett. 1981, 22, 1247.

13. Decout, J. L.; Lhomme, J. Photochem. Photobiol. 1983, 37, 155.

14. Decout, J. L.; Huart, G.; Lhomme, J. Photochem. Photobiol, 1988, $48,583$.

15. Decout, J.; Lhomme, J. Photochem. Photobiol, 1988, 48, 597.

16. Castellan, A.; Desvergne, J. P. Photochem. Photobiol. 1981, $34,183$.

17. (a) Yoo, D. J.; Hyun, S.-H.; Shim, S. C. Bull. Korean Cheni. Soc. 2001, 22(6). 575. (b) Yoo, D. J.; Park, H.-D.; Kim, A. R.; Rho, Y. S.; Shim, S. C. Bull. Korean Chem. Soc, 2002, 23(9), 1315.

18. Armarego, W. L. F.; Petrin, D. D. Purification of Laboraton: Chemicals, 4h ed.; Oxford: Butterworth-Heinemann, 1996.

19. Brokke, M. E.; Christensen, B. E. J. Org. Chem. 1958, 23, 589.

20. Takatsuka, R.; Uno, K.; Toda, F.; Iwakura, Y. J. Pohmi. Sci. Pohm. Chem. Ed. 1977, 15, 2997.

21. Leonard, N. J.; Ito, K. J. Am. Chem. Soc. 1973, 95, 4010.

22. Bolte, J.; Demuynck, C.; Lhomme, J. J. Am. Chem. Soc. 1976, 98 , 613.

23. Mutai, K.; Gruber, B. A.; Leonard, N. J. J. Am. Chen! Soc. 1975. 97,4095 . 